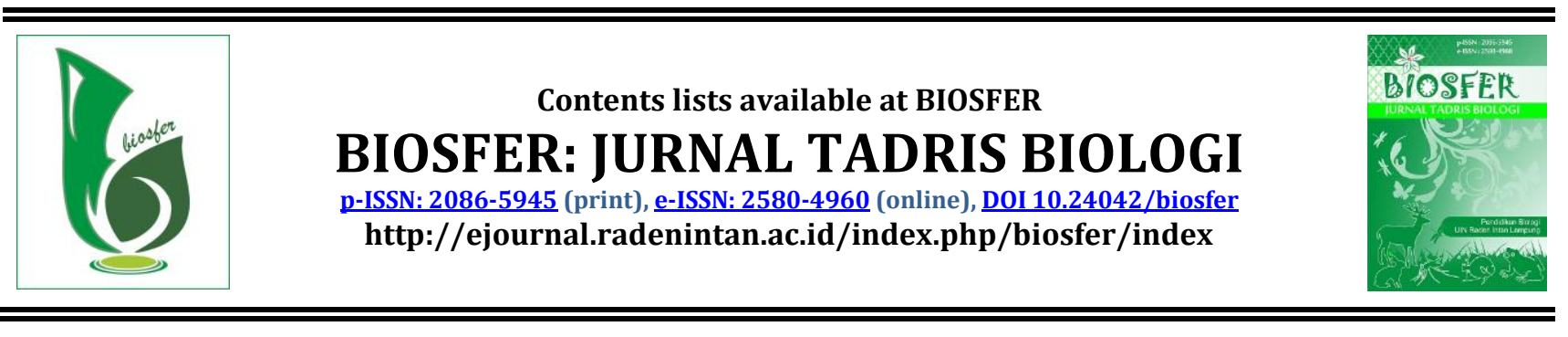

\title{
Vigor Testing of 15 Lots of Soybean (Glycine max L.) Seeds Stored for 12 Months at Low Temperatures
}

\author{
Desi Rizki Amelia ${ }^{1 *}$, Yayuk Nurmiaty ${ }^{2}$, Niar Nurmauli ${ }^{3}$, Agustiansyah $^{4}$, Ermawati $^{5}$ \\ 1, 2, 3, 4, 5 Universitas Lampung, Indonesia
}

\begin{abstract}
ARTICLE INFO
Article History

Received : April 17th 2020

Accepted : May 19th 2020

Published : June 29th 2020

Keywords:

Superior Varieties;

Low Temperature;

Suboptimum;

SP-36 Fertilizer Dosage.

${ }^{*}$ Correspondence Address: akundesirizki@gmail.com

ABSTRACT

The purpose of this study was to determine the vigor growth strength of Anjasmoro, Grobogan, and Burangrang seed varieties based on three doses categories of SP-36 fertilizer stored for 12 months. The treatment was done separately by separating 15 seed lots. The mean value was determined using the Orthogonal contrast test. The results showed that the large-seeded soybean varieties (Grobogan and Burangrang) had higher seed vigor compared to the small-seeded soybean varieties (Anjasmoro) based on the variables of the germination speed, vigor index, normal dry weight, germination growth, and maximum growth potential. The Grobogan variety produced higher seed vigor than Burangrang variety based on vigor index and germination. Anjasmoro and Grobogan varieties without fertilization produced a lower vigor compared to the one with recommended fertilizer doses (100 and 150 $\mathrm{kg} / \mathrm{ha}$ ) and above the recommended fertilizer doses (200 and 250 $\mathrm{kg} / \mathrm{ha}$ ) based on the rate of germination growth and the vigor index. Grobogan variety with recommended fertilizer dose (100 kg/ha) had the highest seed vigor compared to other varieties.
\end{abstract}

\section{Pengujian Vigor 15 Lot Benih Kedelai (Glycine Max L.) Yang Disimpan 12 Bulan Pada Suhu Rendah}

ABSTRAK: Tujuan penelitian ini untuk Mengetahui vigor kekuatan tumbuh benih kombinasi Varietas Anjasmoro, Grobogan, dan Burangrang pada tiga kategori dosis pupuk SP-36 yang telah disimpan 12 bulan. Rancangan perlakuan disusun secara tunggal yaitu 15 lot benih dan pemisahan nilai tengah menggunakan uji Orthogonal contrass. Hasil penelitian menunjukan varietas kedelai berbiji besar (Grobogan dan burangrang) lebih tinggi vigor benihnya dari varietas kedelai berbiji kecil (Anjasmoro) berdasarkan variabel kecepatan perkecamabahan, indeks vigor, bobot kering kecambah normal, daya berkecamabah dan potensi tumbuh maksimum. Perbandingan varietas Grobogan menghasilkan vigor benih yang lebih tinggi dari varietas Burangrang berdasarkan variabel indeks vigor dan daya berkecambah. Varietas Anjasmoro dan Grobogan tanpa pemupukan menghasilkan vigor yang lebih rendah dibandingkan dengan penambahan dosis pupuk rekomendasi (100 dan $150 \mathrm{~kg} / \mathrm{ha}$ ) dan diatas rekomendasi (200 dan $250 \mathrm{~kg} / \mathrm{ha}$ ) berdasrkan variavel kecepatan perkecmabahan dan indeks vigor. Varietas Grobogan dengan 


\section{INTRODUCTION}

Soybean (Glycine max. L) production in Indonesia has increased from year to year to meet industrial demands and animal feed (Pratama dkk., 2017; Siti dkk., 2016; Tatipata dkk., 2010). Soybeans are the most important component of concentrate feed (Astuti dkk., 2008; Sudaryanto \& Swastika, 2007). Therefore, the development of the soybean-based food industry and the feed industry has caused demand for soybeans to continue to increase far beyond domestic production (meliza sari, 2015; Sudaryanto \& Swastika, 2007; Swastika dkk., 2011).

Efforts to increase optimal soybean production are achieved through the use of superior quality varieties of seeds and proper fertilization (Nainggolan, 2014; Tengah dkk., 2015). Soybean seeds in the tropics have a faster deteriorating rate during storage (Anggraeni \& Suwarno, 2014; Tatipata dkk., 2010), thereby, reducing the supply of high-quality seeds. The environment and method of storage need to be considered because they will affect seeds' vigor quickly and slowly (Kolo \& Tefa, 2016; Lesilolo dkk., 2018).

The deteriorating rate of soybean seeds during storage is faster compared to other seeds (Terryana dkk., 2016; Umar, 2012; Rohandi, dkk., 2016), caused by rapid loss of vigor which causes the decrease in seed germination (Lesilolo dkk., 2018; Tresniawati dkk., 2014; Umar, 2012), Thus, soybean seeds must be stored in a low-temperature environment so that the quality of the seeds remains high until the end of storage (Enen dkk., 2014; Sucahyono, 2014; , dkk., 2016).

Plants must be fertilized with the right dose of SP-36 (Hayati dkk., 2009; meliza sari, 2015; Silahooy, 2008; Soplanit \& Soplanit, 2018). As for the seeds, optimal fertilization efforts are needed for the viability and vigor during storage. Seed food reserves need to be increased to maintain the vigor of soybean seeds that have been stored for 12 months at low temperatures (Kolo \& Tefa, 2016).

This research was the development of research conducted by (Sari, 2015) on the germination speed of seeds that had been stored for 6 months based on the vigor and the normal dry weight (Nurussintani dkk., 2013; Wulananggraeni dkk., 2016). This research was to find out the vigor of the seeds of three soybean varieties (Anjasmoro, Grobogan, and Burangrang) derived from SP-36 fertilization which has been stored for 12 months.

\section{METHOD}

This research was conducted at the Integrated Field Laboratory (LTPD) Faculty of Agriculture, the University of Lampung from November to December 2018. The type of land used was dry land with limited water which usually expected from rainfall. The land had been cleared of weed and debris and the minimum tillage was fixed using a hoe which then the land plotting was conducted. Three replications were carried out by randomly picking up 50 seeds for each repetition of each plastic unit experiment. Then, the seeds were planted in the field of $5 \times 3 \mathrm{~m}$ plot sizes with $2 \mathrm{~cm}$ planting holes. Fifteen lots of soybean seeds were planted lengthwise with a spacing of $15 \times 8 \mathrm{~cm}$.

The homogeneity of the variances was tested using the Bartlett test and data additivity was tested by the Tukey test as the assumption for the variance analysis of the randomized group design. If the assumptions of the analysis of the variance have been fulfilled, then the separation of the mean values should be continued using the orthogonal contrast test at the significance level of $5 \%$. 


\section{RESULTS AND DISCUSSION}

Germination rate is the speed of seed to germinate normally. This test was also carried out within 3 replications by taking 50 seeds randomly for each test from each plastic unit of the experiment which then planted in the field like normal seeds germination test. Observation of the germination speed was carried out at 2-7 DAP (Days after Planting).

Grobogan and Burangrang varieties had a better germination speed than Anjasmoro variety by $7.29 \%$. Overall comparison of the Anjasmoro variety combination resulted in no different speed of germination. Grobogan variety with the recommended addition doses of SP-36
(100 and $150 \mathrm{~kg} / \mathrm{ha}$ ) resulted in a better germination speed compared to the addition of the above-recommended doses (200 and $250 \mathrm{~kg} / \mathrm{ha}$ ) with a difference of $10.58 \%$. in the Grobogan variety, the addition of $100 \mathrm{~kg} / \mathrm{ha}$ of SP-36 fertilizer was better than the addition of $150 \mathrm{~kg} / \mathrm{ha}$ with a difference of $8.11 \%$. Each comparison on the Burangrang variety resulted in no different germination rate.

The vigor index is the percentage of normal sprouts on the first observations and also serves as an indicator to determine the speed and uniformity of germination. The results of the comparison of the Vigor Index on 15 lots of seeds fertilized by SP-36 can be seen in Table 1.

Table1.The Orthogonal Contrast Test Results of Vigor Index on 15 Soybean Seed Lots

\begin{tabular}{|c|c|c|c|}
\hline \multirow[t]{2}{*}{ Comparison } & \multicolumn{3}{|c|}{ Vigor Index } \\
\hline & $\mathbf{Q}$ & Difference \% & Fobserved \\
\hline \multicolumn{4}{|l|}{ The Effects of Three Soybean Varieties } \\
\hline P1: Anjasmoro +SP-36VS Grobogan + SP-36 dan Burangrang +SP-36 & 0,48 & 2,14 & 7,90 \\
\hline P2: Grobogan +SP-36 VS Burangrang +36 & $-0,3$ & 2,64 & 9,26 \\
\hline \multicolumn{4}{|l|}{ The Combination Effects of Anjasmoro Variety and SP-36 Fertilizer } \\
\hline $\begin{array}{l}\text { P3: Anjasmro without fertilization VS recommended fertilization dosage (100 } \\
\text { and } 150 \mathrm{~kg} / \mathrm{ha} \text { ) }\end{array}$ & 0,68 & 26,56 & 23,80 \\
\hline $\begin{array}{l}\text { P4: Anjasmoro+recommended SP-36 dosage (100 dan } 150 \mathrm{~kg} / \mathrm{ha} \text { ) VS over the } \\
\text { recommended dosage (200 dan } 250 \mathrm{~kg} / \mathrm{ha})\end{array}$ & 0,04 & & 0,41 \\
\hline $\begin{array}{l}\text { P5: Anjasomoro +recommended SP-36 dosage }(100 \mathrm{~kg} / \mathrm{ha}) \text { VS recommended } \\
\text { dosage }(150 \mathrm{~kg} / \mathrm{ha})\end{array}$ & 0,08 & & 3,29 \\
\hline $\begin{array}{l}\text { P6: Anjasmoro + over the recommended SP-36 dosage }(200 \mathrm{~kg} / \mathrm{ha}) \text { VS over the } \\
\text { recommended dosage }(250 \mathrm{~kg} / \mathrm{ha})\end{array}$ & 0,04 & & 0,82 \\
\hline \multicolumn{4}{|l|}{ The Combination Effects of Grobogan Variety and SP-36 Fertilizer } \\
\hline $\begin{array}{l}\text { P7: Grobogan without fertilization VS recommended fertilization dosage (100 } \\
\text { and } 150 \mathrm{~kg} / \mathrm{ha} \text { ) }\end{array}$ & $-0,13$ & & 0,87 \\
\hline $\begin{array}{l}\text { P8: Grobogan + recommended SP-36 dosage (100 dan } 150 \mathrm{~kg} / \mathrm{ha}) \text { VS over the } \\
\text { recommended dosage ( } 200 \mathrm{dan} 250 \mathrm{~kg} / \mathrm{ha})\end{array}$ & $-0,01$ & & 0,02 \\
\hline $\begin{array}{l}\text { P9: Grobogan +recommended SP-36 dosage }(100 \mathrm{~kg} / \mathrm{ha}) \text { VS recommended } \\
\text { dosage }(150 \mathrm{~kg} / \mathrm{ha})\end{array}$ & $-0,02$ & & 0,02 \\
\hline $\begin{array}{l}\text { P10: Grobogan + over the recommended SP-36 dosage }(200 \mathrm{~kg} / \mathrm{ha}) \text { VS over the } \\
\text { recommended dosage }(250 \mathrm{~kg} / \mathrm{ha})\end{array}$ & $-0,03$ & & 0,46 \\
\hline \multicolumn{4}{|l|}{ The Combination Effects of Burangrang Variety and SP-36 Fertilizer } \\
\hline $\begin{array}{l}\text { P11: Buragrang without fertilization VS recommended and over the } \\
\text { recommended dosages }\end{array}$ & $-0,13$ & & 0,87 \\
\hline P12: Burangrang + recommended SP-36 dosage & 0,05 & & 0,64 \\
\hline $\begin{array}{l}\text { P13: Buragrang+ recommended SP-36 dosage }(100 \mathrm{~kg} / \mathrm{ha}) \text { VS recommended SP- } \\
36 \text { dosage }(150 \mathrm{~kg} / \mathrm{ha})\end{array}$ & 0,07 & & 2,52 \\
\hline $\begin{array}{l}\text { P14: Burangrang +over the recommended SP-36 dosage }(200 \mathrm{~kg} / \mathrm{ha}) \text { VS over the } \\
\text { recommended dosage }(250 \mathrm{~kg} / \mathrm{ha})\end{array}$ & $-0,04$ & & 0,82 \\
\hline
\end{tabular}

Grobogan and Burangrang varieties had better vigor index values than
Anjasmoro variety with a difference of $2.14 \%$. Grobogan variety had a better vigor 
index compared to the Burangrang variety with a difference of $2.64 \%$. Anjasmoro variety given the recommended dosage of SP-36 fertilizer (100 and $150 \mathrm{~kg} / \mathrm{ha}$ ) and over the recommended dosage (200 and $250 \mathrm{~kg} / \mathrm{ha}$ ) produced a higher vigor index compared to the one without fertilization with a difference of $26.56 \%$. the other comparisons generated no difference vigor index.

The dry weight of normal sprouts was measured by the normal seed sprout test. The sprouts that grew normally from each experimental unit were separated from the cotyledons which then wrapped and dried in a Mammert type oven at $80^{\circ} \mathrm{C}$ for $3 \times 24$ hours or until the dry weight reached a constant value. The weighing process was done by Ohaus type analytical balance.

The comparison results of the dry weight of 15 lots of normal sprouts given the SP-36 fertilizer can be seen in Table 2.

Table2. The Orthogonal Contrast Test Results Oon Dry Weight on 15 Soybean Seed Lots

\begin{tabular}{|c|c|c|c|}
\hline \multirow[t]{2}{*}{ Comparison } & \multicolumn{3}{|c|}{ Vigor Index } \\
\hline & $\mathbf{Q}$ & Difference \% & Fobserved \\
\hline \multicolumn{4}{|l|}{ The Effects of Three Soybean Varieties } \\
\hline P1: Anjasmoro +SP-36VS Grobogan + SP-36 dan Burangrang +SP-36 & 0,001 & & 0,0361 \\
\hline P2: Grobogan +SP-36 VS Burangrang +36 & 0,001 & & 0,1083 \\
\hline \multicolumn{4}{|l|}{ The Combination Effects of Anjasmoro Variety and SP-36 Fertilizer } \\
\hline $\begin{array}{l}\text { P3: Anjasmro without fertilization VS recommended fertilization dosage (100 } \\
\text { and } 150 \mathrm{~kg} / \mathrm{ha} \text { ) }\end{array}$ & 0,001 & & 0,3661 \\
\hline $\begin{array}{l}\text { P4: Anjasmoro+recommended SP-36 dosage (100 dan } 150 \mathrm{~kg} / \mathrm{ha} \text { ) VS over the } \\
\text { recommended dosage ( } 200 \text { dan } 250 \mathrm{~kg} / \mathrm{ha})\end{array}$ & 0,001 & & 0,2708 \\
\hline $\begin{array}{l}\text { P5: Anjasomoro +recommended SP-36 dosage (100kg/ha) VS recommended } \\
\text { dosage }(150 \mathrm{~kg} / \mathrm{ha})\end{array}$ & 0,001 & & 0,7799 \\
\hline $\begin{array}{l}\text { P6: Anjasmoro + over the recommended SP-36 dosage }(200 \mathrm{~kg} / \mathrm{ha}) \text { VS over the } \\
\text { recommended dosage }(250 \mathrm{~kg} / \mathrm{ha})\end{array}$ & $\overline{0}, \mathbf{0} 01$ & & 0,5416 \\
\hline \multicolumn{4}{|l|}{ The Combination Effects of Grobogan Variety and SP-36 Fertilizer } \\
\hline $\begin{array}{l}\text { P7: Grobogan without fertilization VS recommended fertilization dosage (100 } \\
\text { and } 150 \mathrm{~kg} / \mathrm{ha} \text { ) }\end{array}$ & 0,001 & & 0,0195 \\
\hline $\begin{array}{l}\text { P8: Grobogan + recommended SP-36 dosage (100 dan } 150 \mathrm{~kg} / \mathrm{ha}) \text { VS over the } \\
\text { recommended dosage ( } 200 \text { dan } 250 \mathrm{~kg} / \mathrm{ha})\end{array}$ & 0,001 & & 1,1307 \\
\hline $\begin{array}{l}\text { P9: Grobogan +recommended SP-36 dosage (100kg/ha) VS recommended } \\
\text { dosage }(150 \mathrm{~kg} / \mathrm{ha})\end{array}$ & 0,000 & & 0,3466 \\
\hline $\begin{array}{l}\text { P10: Grobogan + over the recommended SP-36 dosage }(200 \mathrm{~kg} / \mathrm{ha}) \text { VS over the } \\
\text { recommended dosage }(250 \mathrm{~kg} / \mathrm{ha})\end{array}$ & $\overline{-}, 001$ & & 1,0616 \\
\hline \multicolumn{4}{|l|}{ The Combination Effects of Burangrang Variety and SP-36 Fertilizer } \\
\hline $\begin{array}{l}\text { P11: Buragrang without fertilization VS recommended and over the } \\
\text { recommended dosages }\end{array}$ & $\begin{array}{c}- \\
0,002 \\
\end{array}$ & & 0,6261 \\
\hline P12: Burangrang + recommended SP-36 dosage & 0,001 & & 0,0108 \\
\hline $\begin{array}{l}\text { P13: Buragrang+ recommended SP-36 dosage }(100 \mathrm{~kg} / \mathrm{ha}) \text { VS recommended SP- } \\
\text { 36 dosage }(150 \mathrm{~kg} / \mathrm{ha})\end{array}$ & 0,001 & & 0,7799 \\
\hline $\begin{array}{l}\text { P14: Burangrang +over the recommended SP-36 dosage }(200 \mathrm{~kg} / \mathrm{ha}) \text { VS over the } \\
\text { recommended dosage }(250 \mathrm{~kg} / \mathrm{ha})\end{array}$ & $\overline{-}, 001$ & & 1,0616 \\
\hline
\end{tabular}

Fifteen lots of seeds from each ratio did not produce the same normal dry weights germination. The fifteen lots of seeds were the combination of three superior varieties (Anjasmoro, Grobogan, and Burangrang). Three categories of SP-36 fertilizer dosages were applied, namely without fertilization (0 $\mathrm{kg} / \mathrm{ha})$, the recommended dosage (100 and $150 \mathrm{~kg} / \mathrm{ha})$, and over the recommended dosage $(200$ and $250 \mathrm{~kg} / \mathrm{ha}$ ). The seeds had been stored for 12 months at low temperatures (16.42 $19.58^{\circ} \mathrm{C}$ ) and $\mathrm{RH}(50.8-69.2 \%)$. The vigor test was done under suboptimum environmental conditions (lack of water) where the environmental conditions (wind, 
temperature, humidity, and light) could not be controlled. To meet the water needs, the soybean plants were watered in the morning and the evening. Fifteen lots of seeds were planted on humus soil type which is soil formed from weathering leaves and tree trunks, has dark soil characteristics, loose, and highly fertile.

Disease rate, normal vigor index, and normal dry weight germination are the benchmarks in seed vigor testing (Nurussintani dkk., 2013). Germination and maximum growth potential serve as the supporting variable.

The best result was found in Grobogan variety with $100 \mathrm{~kg} / \mathrm{ha} \mathrm{SP}-36$ fertilizer dosage based on the variables of germination speed and the vigor index. The lowest combination result was found in Anjasmoro and Grobogan varieties without fertilization based on the germination speed and the vigor index. The combination between Grobogan variety and recommended fertilizer dosage (100 and $150 \mathrm{~kg} / \mathrm{ha}$ ) produced higher seed vigor than the over the recommended dosage (200 and $250 \mathrm{~kg} / \mathrm{ha}$ ) based on germination speed variable. The other comparisons were not significantly different in producing seeds' vigor.

Grobogan and Burangrang varieties had a higher vigor than Anjasmoro variety based on germination speed and the vigor index variables. The results were also supported by the germination speed and maximum growth potential. Furthermore, Grobogan variety produced higher vigor compared to varieties with the vigor index based on the vigor index and germination variables.

This research supports the statement of (Rahmawati, 2018) who states that phytin is a form of storage of phosphorus in seeds. Within seeds, phytin is used as a source of food reserves and seed energy during the germination period. The increase in the content of seed food reserves will increase the speed of germination, vigor index, and other components of seed quality.
This study also supports the research conducted by Thoyyibah et al., (2014) who reveals that phosphorus could increase the weight of 100 soybean seeds (Komponen dkk., 2013) and larger-sized seeds contain more food reserves to increase seeds' vigor (Anggraeni \& Suwarno, 2014; Nuraini dkk., 2016; Wulandari dkk., 2015). The research conducted by (Siti dkk., 2016) revealed that $25 \mathrm{~kg} /$ ha fertilizer can increase the growth rates of Grobogan variety and $50 \mathrm{~kg} / \mathrm{ha}$ of $\mathrm{P}$ fertilizer decreased the growth rate of Anjasmoro and Agromulyo varieties. The Burangrang variety did not affect by the $\mathrm{P}$ fertilizer.

The plants' growth suppression rate after being given the $\mathrm{P}$ fertilizer at a dose of $50 \mathrm{~kg} / \mathrm{ha}$ occurred because the required nutrients exceeded the plants' needs so that the nutrients cannot be utilized optimally by the plants. Meanwhile, the root canopy ratio indicated that there was a difference in the response of the varieties to the application of $\mathrm{P}$ fertilizer. The Grobogan's root canopy increased almost twice after being given $\mathrm{p}$ fertilizer $50 \mathrm{~kg} / \mathrm{ha}$ while the Anjasmoro' root canopy ratio was better without fertilization. The fertilized did not affect Burangrang and Agromulyo varieties. It can be concluded that fertilization had different genetic responses between variables. Each variety also had different responses to external factors, such as administering a certain dose of macro fertilizer (Floratek, 2010). reveals that the combination of several soybean varieties and high phosphate fertilizer affects the growth and yield of production (Jayasumatra, 2012).

Only a small amount of phosphorus content is needed and absorbed into soybean seeds, which is around $10-20 \%$. Thus, optimum fertilization does not always correlate with seed quality (Rasyid, 2013). Several environmental factors that influenced the growth of soybean seeds are temperature, light, rainfall, soil moisture, and nutrients.these factors are very important because they will affect the 
quality of seeds during seed formation and ripening.

This research is beneficial to know the combination between the varieties and dosage of SP-36 fertilizer related to vigor. This research was the continuation of research conducted by (meliza sari, 2015) who discovered that 15 lots of seeds within 6 months storage produced $94 \%$ germination capacity, 38\% of germination rate, and $9 \%$ of moisture content. Further research was carried out to see the growth rate and vigor after the soybean had been stored for 12 months at low temperatures $\left(18 \pm 1.58^{\circ} \mathrm{C}\right)$ and humidity $(60 \pm 9.2 \%)$. The vigor index, germination rate, and the normal dry weight are the benchmark in seeds' vigor testing (Swastika dkk., 2011).

\section{CONCLUSIONS AND SUGGESTIONS}

Based on the results of research and discussion, the following conclusions are generated: Grobogan and Burangrang varieties have higher seed vigor than Anjasmoro variety. The combination of the Grobogan variety and SP-36 fertilizer at the dosage of $100 \mathrm{~kg} / \mathrm{ha}$ yielded the highest seed vigor. The combination of the Anjasmoro, Grobogan, and Burangrang varieties without fertilization showed the lowest seed vigor based on the germination speed, vigor index, germination capacity, and maximum growth potential.

It is recommended to store the soybean seeds in a low-temperature storage room. Grobogan variety should be combined with SP-36 fertilizer dosages of $100 \mathrm{~kg} / \mathrm{ha}$ because the addition of fertilizer doses does not increase seeds' vigor. It is recommended for further researchers to make this study as reference material.

\section{REFERENCES}

Anggraeni, N. D., \& Suwarno, F. C. (2014). Kemampuan Benih Kedelai (Glycine max L.) untuk Mempertahankan Viabilitasnya setelah Didera dengan Etanol. Buletin Agrohorti, 1(4), 34. https://doi.org/10.29244/agrob.1.4.3444

Astuti, S., Pengajar, S., Teknologi, J., Pertanian, I., Pertanian, F., Lampung, U., Soemantri, J., No, B., Lampung, B., \& 35145, L. (2008). Isoflavon Kedelai Dan Potensinya Sebagai Penangkap Radikal Bebas. 13(2), 126-136.

Destiana, I., Darmawati, E., \& Pujantoro, L. (2016). The Effect of Plastic Packaging Materials on Soybean Seed Quality During Storage. Jurnal Keteknikan Pertanian, 04(1), 45-52. https://doi.org/10.19028/jtep.04.1.4552

Enen, R., Manggung, R., Ilyas, S., Bakhtiar, Y., Meranti, J., \& Dramaga, K. I. P. B. (2014). Evaluasi Daya Simpan Benih Kedelai yang diberi Perlakuan Pelapisan Benih dengan Cendawan Mikoriza Arbuskula. Jurnal Agronomi Indonesia (Indonesian Journal of Agronomy), 42(2), 103-109. https://doi.org/10.24831/jai.v42i2.842 5

Floratek, J. (2010). Peningkatan Pertumbuhan Dan Produksi Kedelai Melalui Kombinasi Pupuk Organik Lamtorogung Dengan Pupuk Kandang. Peningkatan Pertumbuhan Dan Produksi Kedelai Melalui Kombinasi Pupuk Organik Lamtorogung Dengan Pupuk Kandang, 5(1), $\quad$ 65-73. https://doi.org/10.24815/floratek.v5i1. 387

Hayati, M., Marliah, A., \& Fajri, H. (2009). Dan Hasil Tanaman Kacang Tanah (Arachis hypogaea L.) The Effect of Varieties and Dosage of SP-36 Fertilizer on Growth and Yield of Peanuts ( Arachis Hypogaea L .). 7-13.

Jayasumatra, D. (2012). Pengaruh Sistem Olah Tanah dan Pupuk P Terhadap Pertumbuhan dan Produksi Tanaman Kedelai (Glycine max L. Merril). Agrium, 17(3), 148-154.

Kolo, E., \& Tefa, A. (2016). Pengaruh Kondisi Simpan terhadap Viabilitas dan Vigor 
Benih Tomat (Lycopersicum esculentum Mill). Savana Cendana, 1(03), 112-115. https://doi.org/10.32938/sc.v1i03.57

Komponen, B. T., Hasil, K., Kedelai, T., Kultivar, L. M., Mimi, O., Adang, A., \& Dani, U. (2013). Jurnal Ilmu Pertanian dan Peternakan Volume 1 Nomor 2 Desember 2013. 1, 35-55.

Lesilolo, M. K., Patty, J., \& Tetty, N. (2018). Penggunaan Desikan Abu Dan Lama Simpan Terhadap Kualitas Benih Jagung (Zea mays L.) Pada Penyimpanan Ruang Terbuka. Agrologia, 1(1), 51-59. https://doi.org/10.30598/a.v1i1.298

meliza sari, putri. (2015). Analisis Faktor-Faktor Yang Mempengaruhi Impor Kedelai Di Indonesia. Economica, 4(1), 30-41. https://doi.org/10.22202/economica.2 015.v4.i1.261

Nainggolan. (2014). Prospek Swasembada Kedelai Indonesia. Pangan, 23(1), 8392.

Nuraini, A., Sobardini, D., Suminar, E., \& Apriyanto, H. (2016). Kuantitas dan kualitas hasil benih buncis tegak (Phaseolus vulgaris L.) yang diberi pupuk organik padat dan pupuk organik cair chitosan. Kultivasi, 15(2), 81-85. https://doi.org/10.24198/kultivasi.v15i 2.11869

Nurussintani, W., Damanhuri, \& Purnamaningsih, S. L. (2013). Perlakuan Pematahan Dormansi Terhadap Daya Tumbuh Benih 3 Varietas Kacang Tanah (Arachis hypogaea). Jurnal Produksi Tanaman, 1(1), 86-93.

Pratama, B. J., Nurmiaty, Y., \& Nurmauli, N. (2017). Pengaruh Dosis Pupuk NPK Majemuk Susulan Saat Awal Berbunga (R1) pada Pertumbuhan dan Hasil Tanaman Kedelai (Glycine max [L.] Merill). Jurnal Penelitian Pertanian Terapan, 17(2), 138-144. https://doi.org/10.25181/jppt.v17i2.29 3

Rahmawati, R. (2018). Pengaruh Fosfor Dan Nitrogen Pada Bobot Serta Mutu Benih
Tanaman Kedelai [Glycine max (L.) Merr].

Rasyid, H. (2013). Peningkatan Produksi Dan Mutu Benih Kedelai Varietas Hitam Unggul Nasional Sebagai Fungsi Jarak Tanam Dan Pemberian Dosis Pupuk P. Gamma, 8(2), 46-63.

Rohandi, A., \& Widyani, N. (2016). Perubahan Fisiologis Dan Biokimia Benih Tengkawang Selama Penyimpanan. Jurnal Penelitian Ekosistem Dipterokarpa, 2(1), 9-20. https://doi.org/10.20886/jped.2016.2.1 .9-20

Sari, P. M. (2015). Analisis Faktor-faktor yang Mempengaruhi Konsumsi Kedelai di Indonesia. Journal of Economic and Economic Education Vol, 4(1), 30-41.

Silahooy, C. (2008). Efek Pupuk KCl dan SP-36 Terhadap Kalium Tersedia, Serapan Kalium dan Hasil Kacang Tanah (Arachis hypogaea L.) pada Tanah Brunizem. Jurnal Agronomi Indonesia (Indonesian Journal of Agronomy), 36(2), 126-132. https://doi.org/10.24831/jai.v36i2.136 6

Siti, V., Bagus, T., Biologi, J., Matematika, F., Alam, P., Teknologi, I., \& Nopember, S. (2016). Respon Karakter Fisiologis Kedelai ( Glycine max L .) Verietas Grobogan terhadap Cekaman Genangan. Jurnal Sains dan Seni ITS, 5(2), 71-77.

Soplanit, M. C., \& Soplanit, R. (2018). Pengaruh Bokashi Ela Sagu Pada Berbagai Tingkat Kematangan Dan Pupuk SP-36 Terhadap Serapan P Dan Pertumbuhan Jagung (Zea mays L.) Pada Tanah Ultisol. Agrologia, 1(1). https://doi.org/10.30598/a.v1i1.299

Sucahyono, D. (2014). Teknologi Penyimpanan dan Invigorasi Benih Kedelai. Malang: Balai Penelitian Tanaman Aneka Kacang dan Umbi.

Sudaryanto, T., \& Swastika, D. K. S. (2007). Ekonomi Kedelai di Indonesia. Pusat 
Biosfer: Jurnal Tadris Biologi, 11 (1) (2020) 35 - 42

Desi Rizki Amelia, Yayuk Nurmiaty, Niar Nurmauli, Agustiansyah, Ermawati

Analisis Sosial-Ekonomi dan Kebijakan Pertanian, Bogor, Bps, 1-27.

Swastika, D. K. S., Agustian, A., \& Sudaryanto, T. (2011). Analisis Senjang Penawaran Dan Permintaan Jagung Pakan Dengan Pendekatan Sinkronisasi Sentra Produksi, Pabrik Pakan, Dan Populasi Ternak Di Indonesia. Informatika Pertanian, 2(2), 65-75. https://doi.org/10.1177/17504813177 14127

Tatipata, A., Studi, P., Fakultas, A., \& Universitas, P. (2010). Perubahan Asam Lemak Selama Penyimpanan Benih Kedelai (Glycine Max L. Merr) Dan Hubungannya Dengan Viabilitas Benih. Indonesian Journal of Agronomy, 38(1), 30-35.

https://doi.org/10.24831/jai.v38i1.182 29

Tengah, J., Timur, J., \& Utara, S. (2015). Penerapan SOP Budidaya Untuk Mendukung Temulawak Sebagai Bahan Baku Obat Potensial. Perspektif, 9(2), 78-93.

https://doi.org/10.21082/p.v9n2.2010. $\% \mathrm{p}$

Terryana, R. T., Suhartanto, M. R., \& Qadir, A. (2016). Alat Pengusang Cepat IPB 77-1 MM untuk Penapisan Vigor Daya Simpan Benih Kedelai. Jurnal Penelitian Pertanian Tanaman Pangan, 34(3), 229. https://doi.org/10.21082/jpptp.v34n3. 2015.p229-235

Tresniawati, C., Murniati, E., Eny Widajati, dan, Fisik, P., dan Biokimia Selama Pemasakan Benih dan Studi Rekalsitransi Benih Kemiri Sunan, F., Penelitian Tanaman Industri dan Penyegar Jl Raya Pakuwon km, B., \& Barat, J. (2014). Physical, Physiological and Biochemical Changes during Seed Maturation and Study on Recalcitrancy of Reutealis trisperma Seed. J. Agron. Indonesia, 42(1), 74-79.

Umar, S. (2012). Pengaruh Pemberian Bahan Organik Terhadap Daya Simpan Benih Kedelai \{Glycine max (L.) Merr. ${ }^{*}[$ Effect of Organic Matter Application on
Storage Period of Soybean \{ Glycine max ( L .) Merr .\} Seed ]. Berita Biologi, 11(3), 401-410. https://doi.org/10.2105/ajph.81.7.839

Wulananggraeni, R., Damanhuri, \& Purnamaningsih, S. L. (2016). Pengaruh Perbedaan Tingkat Kemasakan Buah Pada 3 Genotip Mentimun (Cucumis Sativus L.) Terhadap Kualitas Benih. Jurnal Produksi Tanaman, 4(5), 332341.

Wulandari, W., Bintoro, A., \& . D. (2015). Pengaruh Ukuran Berat Benih Terhadap Perkecambahan Benih Merbau Darat (Intsia Palembanica). Jurnal Sylva Lestari, 3(2), 79. https://doi.org/10.23960/jsl2379-88 